\title{
IMPROVING GROWTH AND PRODUCTIVITY OF TOMATO UNDER SALINE CONDITIONS BY FERTILIZATION AND SALINITY HARDENING \\ Shafshak, Nadia S. ${ }^{1}$; S. M. Aid ${ }^{1} ;$ H .S. Khafaga ${ }^{2}$ and Y. A. M. Salama ${ }^{2}$ \\ 1- Horticulture Dept., Faculty of Agric., Moshtohor, Benha University \\ 2- Plant Adaptation Unit, Genetic Resource Dept.. Desert Res. Center
}

\begin{abstract}
This study aimed to investigate some possible approaches to alleviate the negative effects of salinity on tomato plant growth and productivity. Seeds of tomato (Lycopersicon esculentum Mill) hybrid VT737 were sown and seedling were exposed to hardening treatments using four levels of saline irrigation (control $250 \mathrm{ppm}$, low $1500 \mathrm{ppm}$, medium 3000 ppm and high $4500 \mathrm{ppm}$ ) during nursery stage. After transplanting in the open field, all plants were irrigated with saline water with $5500_{ \pm}$ $500 \mathrm{ppm}$ and the standard recommended fertilization dose. Plants were also receiving four experimental fertilization treatments namely control (no additional fertilization), mono potassium phosphate, potassium humate and amino acids.

Recorded data showed that all vegetative and reproductive parameters responded positively to the individual effect of hardening and fertilization treatments and their interactions. The hardening level of $3000 \mathrm{ppm}$ showed the best effect followed by the 4500 level and the least for $1500 \mathrm{pp}$. Meanwhile the fertilization of mon potassium phosphate gave the best results followed by potassium humate then the amino acids. The interactive effect of the treatments appeared to be cumulative on plant response.

Keywords: tomato, salinity, hardening, mono potassium phosphate, humate, amino acids.

\section{INTRODUCTION}

Salt stress is a common consequence of insufficient water supply and/or using poor quality water. Salinity may be naturally exist particularly in arid and semi arid regions such as Egypt. According to Gehad, 2003 most of the saline affected soil is located in the northern middle Nile Delta as well as its eastern and western sides. This problem is usually counteracting the expansion in land reclamation. Salinity is a well known factor affecting negatively growth and production of many crops such as tomato (Hayward and Long, 1943; Sanchez Conde and Azuara,1979; Li, 2000; Tantawy, 2007) and sweet pepper (Pitacco et al., 1990; Zabri et al., 1997; Chartzoulakis and Klapaki, 1998; Abdel-Mawgoud 2002) and their productivity, for tomato (Ehret and Ho, 1986; Ho and Adams, 1989; Li, 2000; Tantawy, 2007) and sweet pepper (Sonneveld, 1979; Abdel-Mawgoud, 2002). The main negative effect of salinity comes from the osmotic effect on plant water uptake which eventually affects growth and yield (Livett, 1980; Abdel-Mawgoud, 2002). The result is the well-known yield reduction. Many trails have been made to alleviate salinity effects with partial success or non-applied results.
\end{abstract}


The aim of this study is to find an applied, environmental-friendly products such as potassium humate and amino acids to improve alleviate the negative effects of salits tomato crop grown under saline conditions.

\section{MATERIALS AND METHODS}

The experiments were conducted in Agric. Research stations location in Ras Sedr, South Sinai governorate. Tomato hybrid VT737 was used in the experimental work of this study to test the proposed treatments in different growth condition. The first was carried out under nursery while the other under the field conditions

\section{Nursery stage (Hardening treatments):}

The experiment was stared on the $15^{\text {th }}$ February during the two growth seasons of 2005 and 2006. Seeds of tomato hybrid were sown in foam trays having 209 holes filled with a growing media having moisture of $60 \%$. The growing media was prepared by mixing 300 liters peatmoss, 100 $\mathrm{kg}$ vermiculite, $500 \mathrm{gm}$ ammonium phosphate, $400 \mathrm{gm}$ ammonium nitrate, $300 \mathrm{gm}$ potassium sulfate, $150 \mathrm{gm}$ micro nutrients mixture (Tradecorp A-Z), $100 \mathrm{~cm}^{3}$ fungicide (Maxium), and $4 \mathrm{~kg}$ Calcium Carbonate. Seed trays were irrigated with tape water for 15 days after which the experimental treatments were applied.

Four salinity levels of irrigation water were applied namely control (tape water $\simeq 250 \mathrm{ppm}$ ), 1500, 3000 and $4500 \mathrm{ppm}$. At each week and for five weeks period, irrigation with the above mentioned salinity levels were applied as follow: First day: irrigation with proposed salinity levels, Second day: Irrigation Fasting, Third day: irrigation with proposed salinity levels, Fourth day: Irrigation Fasting, Fifth day: Leaching with tape water and Six day: Irrigation Fasting. No other treatments were applied in this experiment.

\section{Open field stage (fertilization treatments)}

Plants grown in the nursery and treated with the above mentioned hardening treatments were transplanted into the open field at Ras Sedr Research Station in South Sinai. Mechanical (Table 1) and chemical ( Table 2) analyses of soil used were determined at two depths, $0-15$ and $15-30 \mathrm{~cm}$. Mechanical analysis of soil was performed according to Piper (1950) and Jackson (1958), while the chemical analysis of water and soil was carried out according to Jackson (1958) and Chapman and Pratt (1961).

The irrigation was carried out using water from underground well. The chemical analysis of the irrigation water is shown in Table (3).

Soil was prepared before transplanting by adding cattle manure at $20 \mathrm{~m}^{3} /$ feddan and calcium super phosphate $\left(15.5 \% \mathrm{P}_{2} \mathrm{O}_{5}\right)$ at a standard rate of $350 \mathrm{~kg} / \mathrm{feddan}$. Chemical fertilizers were applied twice before transplanting and near to flowering stage. Ammonium nitrate $(33.5 \% \mathrm{~N})$ and potassium sulfate $(48 \% \mathrm{k} 2 \mathrm{O})$ were added at the rate of 50 and $70 \mathrm{~kg} / \mathrm{feddan}$ respectively as two equal portions at 15 and 30 days after transplanting.

Individual transplants were grown at the bottom of ridges $100 \mathrm{~cm}$ width at $40 \mathrm{~cm}$ apart. Plot area was $1 \times 12=12 \mathrm{~m}^{2}$. The drip irrigation system of GR 16 was used and plants were irrigated daily using saline-well water. 
Table (1): Soil mechanical analysis and soil properties of the experimental farm, at Wadi Sedr, South Sinai.

\begin{tabular}{|c|c|c|c|c|}
\hline Soil depth (cm) & Total sand (\%) & Silt (\%) & Clay (\%) & Texture \\
\hline $0-15$ & 59.0 & 10.5 & 30.5 & Sandy \\
\hline $15-30$ & 56.0 & 12.0 & 32.0 & Sandy \\
\hline
\end{tabular}

Table (2): Soil chemical analysis of the experimental farm, at Wadi Sedr, South Sinai.

\begin{tabular}{|c|c|c|c|c|c|c|c|c|c|}
\hline \multirow{2}{*}{$\begin{array}{l}\text { Soil } \\
\text { depth } \\
(\mathrm{cm})\end{array}$} & \multirow{2}{*}{$\begin{array}{c}E C \\
(\mathrm{dS} / \mathrm{m})\end{array}$} & \multirow[b]{2}{*}{ pH } & \multicolumn{3}{|c|}{ Soluble anions (ppm) } & \multicolumn{4}{|c|}{ Soluble cations (ppm) } \\
\hline & & & $\mathrm{HCO}_{3}{ }^{-}$ & $\mathrm{Cl}^{-}$ & $\mathrm{SO}_{4}^{--}$ & $\mathrm{Ca}^{++}$ & $\mathrm{Mg}^{++}$ & $\mathrm{Na}^{+}$ & $\mathrm{K}^{+}$ \\
\hline $0-15$ & 10.00 & 7.5 & 11.0 & 1210 & 5.0 & 270 & 144 & 685 & 13 \\
\hline $15-30$ & 9.00 & 7.2 & 13.3 & 1200 & 4.8 & 220 & 110 & 670 & 15 \\
\hline
\end{tabular}

Table (3): Chemical analysis of irrigation water (underground well) of the experimental farm, at Wadi Sedr, South Sinai.

\begin{tabular}{|c|c|c|c|c|c|c|c|c|c|}
\hline \multirow{2}{*}{$\begin{array}{l}\text { Water } \\
\text { sample }\end{array}$} & \multirow{2}{*}{$\begin{array}{c}E C \\
(\mathrm{dS} / \mathrm{m})\end{array}$} & \multirow{2}{*}{$\mathrm{pH}$} & \multicolumn{3}{|c|}{ Soluble anions (ppm) } & \multicolumn{4}{|c|}{ Soluble cations (ppm) } \\
\hline & & & $\mathrm{HCO}_{3}{ }^{-}$ & $\mathrm{Cl}^{-}$ & $\mathrm{SO}_{4}^{--}$ & $\mathrm{Ca}^{++}$ & $\mathrm{Mg}^{++}$ & $\mathrm{Na}^{+}$ & $\mathrm{K}^{+}$ \\
\hline Average & $8.59^{*}$ & 7.4 & 0.50 & 1540 & 6.1 & 518 & 275 & 807 & 9 \\
\hline
\end{tabular}

Fertilization treatments with specific compounds were applied with irrigation water every ten days. Fertilization treatments were as follow: Potassium humate (Humic acid $85 \%-12 \% \mathrm{~K}_{2} \mathrm{O}$ ) in a rate of $4 \mathrm{gm} / \mathrm{liter}$ water, Mixture of amino acids in a rate of $2 \mathrm{gm} / \mathrm{liter}$, Mono potassium phosphate in a rate of $3 \mathrm{gm} / \mathrm{liter}$ and control.

Measurements:

Vegetative, physiological and chemical measurements were recorded at 75 days after transplanting in the open field.

\section{Vegetative measurements:-}

Plant height $(\mathrm{cm})$ was measured from cotyledons level to plant top, Number of branches, Leaf area $\left(\mathrm{cm}^{2}\right)$ was determined using leaf area meter machine model ADC Bioscientific Ltd., Japan, Fresh weight (g) of aerial part (stem and leaves) was determined in gm/plant, Dry weight (g): Sample of plant shoot per replicate was dried in oven $\left(70^{\circ} \mathrm{C}\right)$ until a constant dry weight was reached.

\section{Physiological measurements:-}

Stomatal conductance, Leaf temperature and Transpiration rate using Porometer machine model LI-COR., USA. Osmotic pressure of cell sap at 70 days after transplanting was estimated with relationship between total soluble solids and osmotic pressure according to Gosev (1960). Total Soluble Solids (T.S.S.\%) in leaves at 70 days after transplanting was determined by using hand referactometer according to A.O.A.C. (1990).

\section{Yield measurements:-}

Number of fruits per plant, Weight of fruits per plant, Average of individual fruit, Total yield, Total Soluble Solids (T.S.S.\%) in fruits was determined by using hand referactometer according to A.O.A.C. (1990).

\section{Statistical design and analysis:}


A total of 16 treatments were a result of a combination of 4 salinity hardening treatments $\times 4$ fertilization treatments. Treatments were arranged in a split plot design with three replicates. Fertilization were placed in the main plot and hardening in the sub-plot. Analytical procedures were as described by Snedecore and Cochran (1991).

\section{RESULTS AND DISCUSSION}

\section{Vegetative growth: \\ Effect of fertilization treatments:}

Table (4) shows the effects of salinity and fertilization treatments on plant vegetative growth. In this study as previous studies, salinity reduced plant height (Achilea, 2002; Agong et al.,2004 and Hajer et al. ,2006) and leaf area (Li and Stanghellini, 2001; Mulholland et al., 2002; Maggio et al., 2004; and Agong et al., (2004), fresh weight (Hassan, 1999; Li, 2000; Sonneveld, 2000, Amico et al., 2003 and Hajer et al. ,2006) as well as dry weight (Li, 2000; and Yurtseven et al., 2003). However the application of fertilizers such as mono potassium phosphate and potassium humate overcame this negative effect probably due to the presence of potassium as reported by Eata (2001) and Achilea (2002). Leaf area reduction was also overcame by $\mathrm{K}$ application under saline conditions (Al-Karaki, 2000; Eata, 2001; Ahmed, 2003). This may be due to the competition between potassium and Sodium for absorption and/or the regulation of $\mathrm{K}$ to plant water relation which reflects on cell elongation. The same explanation can be held true for the effect of $\mathrm{K}$ on a higher leaf area of the plant under saline conditions. Mono potassium phosphate was superior in its positive effect followed by potassium humate while amino acid had the lowest positive effect in improving plant height, number of branches and leaf area compared to control treatment (Table 4). These effects were significantly higher compared to control as well as among the fertilization treatments themselves. Similar trend was observed in both seasons for the fresh and dry weight of the shoot with one exception in the fresh weight of the shoots, where there was no significant difference between the positive effects of potassium humate and amino acid treatments. Using $\mathrm{K}$ fertilizer under saline condition alleviated saline effect and improved plant fresh weight as reported by Soubeih, 1998; Hassan, 1999. As the fresh weight depends mainly on plant water status and $\mathrm{K}$ has a major role in controlling this status, therefore this can be the explanation for the role of $\mathrm{K}$ in improving this parameter. Since potassium is the main nutrient in controlling stomatal behavior hence plant water status and photosynthesis, it can expected that it may improve plant dry matter production which has been observed. The presence of phosphate in the same fertilizer enhanced the response of the plant to the applied dose and this may be the reason for the highest response to mono potassium phosphate application compared to other treatments. $\mathrm{P}$ was reported to decrease as salinity increased (Ahmed, 1998; Nofual et al., 2000; Eata, 2001; and Shibli et al., (2007) But $\mathrm{K}$ increased $\mathrm{P}$ content in the plants (Eata, 2001; Ahmed, 2003) which means that the presence of the two elements enhance each other which eventually reflect on plant growth and production. 
Vegetative growth was positively correlated with dry matter production, as well as phosphorus level in plant (Valenzuela and Gallardo, 2001). The effect of $P$ may come from its essential role in energy compounds in the plants as well as in the phospholipids which is the main component of cell walls.

\section{Effect of hardening treatments:}

Hardening treatments, generally, improved plant vegetative growth parameters compared to control as shown in Table (4). The medium hardening level of $3000 \mathrm{ppm}$ showed superiority in its positive effect on plant growth followed by the high level of $4500 \mathrm{ppm}$ then the low level of 1500 $\mathrm{ppm}$. All vegetative parameters studied, plant height, number of branches, total leaf area and shoot fresh and dry weight responded similarly to the hardening treatments. Hardening increased plant tolerance to salinity which reflected on better plant growth and production. Salinity hardening treatments it was for the mung bean increased plant height, leaf area and fresh weight (Ahmed, 2003) as well as dry weight (Taha, 1978). This effect of hardening may come from the effect of hardening on plant osmotic adjustment to higher osmotic pressure in the root zone. This adjustment can be brought about by accumulating nutrients in the plant as hardening was found to increase $\mathrm{P}$ and K content (Taha, 1978 and Ahmed 2003).

\section{Effect of interaction:}

Table (4) shows the interaction between the two treatments which showed a cumulative positive effect on plant height where the combination between mono potassium phosphate and the hardening with medium level (3000 ppm) gave the highest effect allover the treatments. The difference among the treatments was significant. The same trend was observed for the parameters of fresh and dry weights of the shoots. Meanwhile only in the season of 2005 differences resulted from the interaction between the fertilization and hardening treatments on number of branches and total leaf area were not significant at $p<0.05$.

\section{Physiological parameters}

Effect of fertilization treatments:

TSS of the leaves and osmotic pressure as shown in Table (5) for the two seasons of 2005 and 2006 responded positively to the treatments of fertilization. As observed in the vegetative growth, the treatment of mono potassium phosphate resulted in the highest response in those recorded parameters compared to the control. Other fertilization treatments gave also significant positive results compared to control but not as of mono potassium phosphate. Stomatal conductance, transpiration rate and leaf temperature decreased in response to the fertilization treatments. Mono potassium phosphate treatment resulted in the lowest values for the three mentioned parameters. For all physiological parameters studies, the Fertilization treatments can be arranged according to their degree of effect in the following order, mono potassium phosphate, potassium humate and finally amino acid treatment. All these findings can be explained as results of $K$ application which is considered the main key for stomatal behavior which reflects on all measured physiological parameters. 
Table (4): Effect of fertilization and salinity hardening treatments on growth characters of V.T. 737 tomato hybrid in the first and second seasons (2005 and 2006)

\begin{tabular}{|c|c|c|c|c|c|c|c|c|c|c|c|}
\hline \multicolumn{2}{|c|}{ Treatments } & \multirow{2}{*}{\multicolumn{2}{|c|}{$\begin{array}{l}\text { Plant } \\
\text { height } \\
\text { (cm) }\end{array}$}} & \multirow{2}{*}{\multicolumn{2}{|c|}{$\begin{array}{c}\text { No. of } \\
\text { branches } / \\
\text { plant }\end{array}$}} & \multirow{2}{*}{\multicolumn{2}{|c|}{$\begin{array}{l}\text { Leaf } \\
\text { area / } \\
\text { plant } \\
\left(\mathrm{cm}^{2}\right)\end{array}$}} & \multirow{2}{*}{\multicolumn{2}{|c|}{$\begin{array}{c}\text { Shoot fresh } \\
\text { weight/ plant } \\
(\mathrm{gm})\end{array}$}} & \multirow{2}{*}{\multicolumn{2}{|c|}{$\begin{array}{c}\text { Shoot dry } \\
\text { weight/ plant } \\
\text { (gm) }\end{array}$}} \\
\hline $\begin{array}{c}\text { Fertilization } \\
\text { (A) }\end{array}$ & $\underset{\text { Salinity }}{\text { hardening }(B)^{\star}}$ & & & & & & & & & & \\
\hline \multicolumn{2}{|l|}{ Seasons } & 1st & $2^{\text {nd }}$ & 1. & $2^{\text {nd }}$ & $1 \stackrel{s t}{t}$ & $2^{\text {nd }}$ & 1 st & $2^{\text {nd }}$ & 1st & $2^{\text {nd }}$ \\
\hline \multirow{4}{*}{ Control } & & 4.33 & 55.33 & 8.00 & 8.33 & 9.23 & 9.97 & \multirow{4}{*}{\multicolumn{4}{|c|}{\begin{tabular}{|c|c|c|c|}
206.00 & 230.00 & 158.00 & 163.00 \\
246.00 & 288.67 & 169.00 & 174.00 \\
286.00 & 338.67 & 180.67 & 186.33 \\
262.00 & 311.33 & 166.00 & 171.67 \\
\end{tabular}}} \\
\hline & & & \begin{tabular}{|l|}
57.33 \\
\end{tabular} & \begin{tabular}{|l|}
8.33 \\
\end{tabular} & \begin{tabular}{|l|}
8.67 \\
\end{tabular} & 11.67 & 12.33 & & & & \\
\hline & Medit & & 6 & 9 & \begin{tabular}{|l|}
9.00 \\
\end{tabular} & 14.70 & 14.93 & & & & \\
\hline & & & & & & 12.00 & 12.73 & & & & \\
\hline \multicolumn{2}{|l|}{ Mean } & & & 8.50 & 67 & 11.90 & 12.49 & \multicolumn{2}{|c|}{\begin{tabular}{|l|l|}
50.00292 .17 \\
\end{tabular}} & 168.42 & 173.75 \\
\hline \multirow{4}{*}{$\begin{array}{l}\text { Potassium } \\
\text { Humate }\end{array}$} & UVim & & & & & 11.23 & 11.5 & 51.00 & 281.67 & & .00 \\
\hline & Low & & & & & 13.23 & 14.2 & & $\Omega_{0}$ & & .33 \\
\hline & Medic & & & & & 17.08 & 18. & & & & .67 \\
\hline & & & & & & & & & & & \\
\hline \multicolumn{2}{|l|}{ Mean } & & & & 7 & 13.88 & 14.80 & & 0 & 19 & 9.75 \\
\hline \multirow{4}{*}{$\begin{array}{l}\text { Mono } \\
\text { Potassium } \\
\text { Phosphate }\end{array}$} & Con & & & & & 12.00 & 12. & & 30 & 18 & 3.00 \\
\hline & -ow (1 & & & & & 14.07 & 16. & & & & 00 \\
\hline & Medil & & & & & 1 & 21. & & & & 00 \\
\hline & High & & & & & & & & & & \\
\hline \multicolumn{2}{|l|}{ Mean } & & & \multirow{2}{*}{\multicolumn{2}{|c|}{ 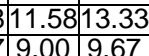 }} & & 7. & & & & .58 \\
\hline \multirow{4}{*}{ Amino Acid } & Cont & & & & & \begin{tabular}{|l|}
9.57 \\
\end{tabular} & 10 & & & & 33 \\
\hline & Low & & & \multicolumn{2}{|c|}{10.0011 .00} & 12.03 & 13. & & & & .00 \\
\hline & Medic & & & & 11.67 & 15.57 & 16. & & & & 3.33 \\
\hline & Non & & & \multirow{2}{*}{\multicolumn{2}{|c|}{\begin{tabular}{|l|}
9.67 \\
983
\end{tabular}}} & & & & & & .67 \\
\hline \multicolumn{2}{|l|}{ Mean } & & & & & 12.43 & 13.3 & & .83 & 18 & 7.33 \\
\hline & 57. & 59.42 & \multicolumn{2}{|l|}{9.08} & 10.51 & 11.0 & 215 & 712 & 16 & 72.08 \\
\hline \multirow{3}{*}{$\begin{array}{l}\text { General } \\
\text { mean for }(A) \\
\text { treatments }\end{array}$} & ow & & & \multirow{2}{*}{\multicolumn{2}{|c|}{$\frac{10.0011 .00}{11.0812 .33}$}} & 12.7 & & & & & 3.58 \\
\hline & edi & & & & & 16. & 17. & & & & 22.33 \\
\hline & & & & \multicolumn{2}{|c|}{10.2511 .50} & & & & & & \\
\hline \multirow{3}{*}{$\begin{array}{l}\text { L.S.D } \\
0.05 \text { for }\end{array}$} & & 0.90 & 0.92 & 0.44 & 0.63 & \begin{tabular}{|l|}
0.84 \\
\end{tabular} & 0.69 & 20.88 & 9.60 & 5.08 & 5.56 \\
\hline & & 0.76 & 0.75 & 0.53 & 0.63 & 0.71 & 0.58 & & & & \\
\hline & & 1.51 & 1.50 & N.S & 1.26 & \begin{tabular}{|l|} 
N.S \\
\end{tabular} & \begin{tabular}{|l|}
1.17 \\
\end{tabular} & & & 8.17 & 7.18 \\
\hline
\end{tabular}

*ppm for salinity

\section{Effect of hardening treatments:}

The salinity hardening treatments showed the same trend observed earlier with other parameters. The medium hardening level 3000 ppm showed the highest positive response on the TSS and osmotic pressure of the leaves followed by the high level of hardening $4500 \mathrm{ppm}$ then the lowest level of $1500 \mathrm{ppm}$ compared to control treatment (Tables 5). Stomatal conductance, transpiration rate and leaf temperature showed a negative response compared to the control treatment. The lowest recorded values for the three parameters were recorded with the medium level of $3000 \mathrm{ppm}$ followed by the high hardening level of $4500 \mathrm{ppm}$ then the $1500 \mathrm{ppm}$ level compared to the control treatment.

\section{Effect of Interaction:}

Data in table (5) showed that the interaction between treatments resulted in a cumulative effect on the observed parameters during the two 
growth seasons. Fertilization treatments enhanced the effect of the hardening treatments which resulted in a higher plant response. The mono potassium phosphate treatment in combination with the hardening level of $3000 \mathrm{ppm}$ gave the best results compared to the control and all other treatments.

Table 5): Effect of fertilization and salinity hardening treatments on some physiological characters on V.T. 737 tomato hybrid in the first and second seasons (2005 and 2006)

\begin{tabular}{|c|c|c|c|c|c|c|c|c|c|c|c|}
\hline \multicolumn{2}{|c|}{ Treatments } & \multirow{2}{*}{\multicolumn{2}{|c|}{$\begin{array}{l}\text { TSS \% of } \\
\text { leaves }\end{array}$}} & \multirow{2}{*}{\multicolumn{2}{|c|}{$\begin{array}{c}\text { Osmotic } \\
\text { pressure } \\
\text { (A.P) }\end{array}$}} & \multirow{2}{*}{\multicolumn{2}{|c|}{$\begin{array}{l}\text { Stom. } \\
\text { Cond. } \\
\left(\mathrm{cms}^{-1}\right)\end{array}$}} & \multirow{2}{*}{\multicolumn{2}{|c|}{$\begin{array}{c}\text { Trans. (mg } \\
\mathrm{cn}^{-2} \mathrm{~s}^{-1} \text { ) }\end{array}$}} & \multirow{2}{*}{\multicolumn{2}{|c|}{$\begin{array}{l}\text { Leaf temp. } \\
\left(\mathrm{C}^{0}\right)\end{array}$}} \\
\hline $\begin{array}{c}\text { Fertilization } \\
\text { (A) }\end{array}$ & $\begin{array}{c}\text { Salinity } \\
\text { hardening }(B)^{\star}\end{array}$ & & & & & & & & & & \\
\hline \multicolumn{2}{|l|}{ Seasons } & 1st & $2^{\text {nd }}$ & 1 st & 2 nd & 1st & $2^{\text {nd }}$ & 1 st & $2^{\text {nd }}$ & 1st & $2^{\text {nd }}$ \\
\hline \multirow{4}{*}{ Control } & Control & 10.07 & 10.13 & 8.17 & 8.20 & 27.97 & 27.50 & 29.63 & 29.17 & 38.83 & 38.47 \\
\hline & Low (1500 ppm) & 10.57 & 10.63 & 8.60 & 8.70 & 25.03 & 24.63 & 25.23 & 25.07 & 37.60 & 37.33 \\
\hline & Medium(3000 ppm) & 10.80 & 10.93 & 9.20 & 9.30 & 22.33 & 21.80 & 24.13 & 23.70 & 36.47 & 36.13 \\
\hline & High (4500 ppm) & 10.63 & 10.73 & 8.87 & 9.00 & 22.93 & 22.43 & 24.57 & 24.10 & 36.73 & 36.57 \\
\hline \multicolumn{2}{|l|}{ Mean } & 10.52 & 10.61 & 8.71 & 8.80 & 24.57 & & & 25.51 & 37.41 & 37.13 \\
\hline \multirow{4}{*}{$\begin{array}{l}\text { Potassium } \\
\text { Humate }\end{array}$} & Control & 10.57 & 10.60 & 8.47 & 8.47 & 23.83 & 23.60 & 26.47 & 26.13 & 37.77 & 37.47 \\
\hline & Low (1500 ppm) & 10.77 & 10.87 & 9.23 & 9.33 & 21.97 & 21.50 & 24.10 & 23.70 & 37.17 & 36.83 \\
\hline & Medium(3000 ppm) & 12.20 & 12.30 & 10.23 & 10.33 & 19.70 & 19.27 & 22.60 & 22.10 & 35.17 & 34.93 \\
\hline & High (4500 ppm) & 11.40 & 11.63 & 9.53 & 9.63 & 20.10 & 19.67 & & 22.83 & 36.07 & 35.87 \\
\hline \multicolumn{2}{|l|}{ Mean } & 11.23 & 11.35 & 9.37 & 9.44 & 21.40 & 21.01 & 24.12 & 23.69 & 36.54 & 36.28 \\
\hline \multirow{4}{*}{$\begin{array}{l}\text { Mono } \\
\text { Potassium } \\
\text { Phosphate }\end{array}$} & Control & 10.70 & 10.80 & 8.57 & 8.57 & 23.03 & 22.83 & 25.53 & 25.43 & 37.23 & 37.07 \\
\hline & Low (1500 ppm) & 10.87 & 11.00 & 9.17 & 9.27 & 19.97 & 19.50 & 22.77 & 22.30 & 35.07 & .80 \\
\hline & Medium(3000 ppm) & 12.50 & 9.37 & 10.60 & 10.73 & 18.50 & 18.07 & 19.60 & 19.10 & 34.00 & 33.77 \\
\hline & High (450c & 11.73 & 11.87 & 9.87 & 10.00 & 19.23 & 18.77 & 20.10 & 19.63 & 34.20 & .07 \\
\hline \multicolumn{2}{|l|}{ Mean } & 11.45 & 10.76 & 9.55 & 9.64 & 20.18 & 19.79 & 22.00 & 21.62 & 35.13 & .93 \\
\hline \multirow{4}{*}{ Amino Acid } & Control & 10.43 & 10.83 & 8.40 & 8.40 & 24.83 & 24.70 & 27.13 & 26.80 & 37.87 & 37.57 \\
\hline & Low (1500 ppm) & 10.63 & 10.80 & 9.02 & 9.03 & 22.93 & 22.43 & 24.80 & 24.27 & 37.57 & 37.47 \\
\hline & Medium(3000 ppm) & 11.53 & 11.63 & 9.47 & 9.60 & 20.10 & 19.70 & 22.63 & 22.43 & 35.60 & 35.47 \\
\hline & High (4500 ppm) & 11.67 & 11.33 & 9.27 & 9.37 & 20.70 & 20.20 & 23.63 & 23.03 & 36.47 & 36.33 \\
\hline \multicolumn{2}{|l|}{ Mean } & 10.94 & 11.08 & 9.04 & 9.10 & 22.14 & 21.76 & 24.55 & 24.13 & 36.88 & 36.71 \\
\hline \multirow{4}{*}{$\begin{array}{l}\text { General } \\
\text { mean for }(A) \\
\text { Treatments }\end{array}$} & Control & 10.44 & 10.52 & 8.40 & 8.41 & 24.92 & 24.66 & 27.19 & 26.88 & 37.93 & 37.64 \\
\hline & Low (1500 ppm) & \begin{tabular}{|l|}
10.71 \\
\end{tabular} & 10.83 & 9.01 & 9.08 & 22.48 & 22.02 & 24.23 & 23.83 & 36.85 & 36.61 \\
\hline & Medium(3000 ppm) & 11.76 & 11.06 & 9.88 & 9.99 & 20.16 & 19.71 & 22.24 & 21.83 & 35.31 & 35.08 \\
\hline & High (4500 ppm) & 11.23 & 11.39 & 9.38 & 9.50 & 20.74 & 20.27 & 22.90 & 22.40 & 35.87 & 35.71 \\
\hline \multirow{3}{*}{$\begin{array}{l}\text { L.S.D } \\
0.05 \text { for }\end{array}$} & $A$ & 0.11 & N.S & 0.10 & 0.08 & 0.18 & 0.26 & 0.34 & 0.22 & 0.09 & 0.17 \\
\hline & $\mathrm{B}$ & 0.09 & N.S & 0.07 & 0.07 & 0.16 & 0.21 & 0.26 & 0.20 & 0.04 & 0.12 \\
\hline & $A \times B$ & 0.17 & N.S & 0.13 & 0.15 & 0.33 & 0.43 & 0.52 & 0.41 & 0.09 & 0.23 \\
\hline
\end{tabular}

${ }^{\star}$ ppm for salinity

\section{Reproductiveity \\ Effect of fertilization treatments:}

$\mathrm{Li} \mathrm{(} \mathrm{2000)} \mathrm{as} \mathrm{well} \mathrm{as} \mathrm{others} \mathrm{(Ragab} \mathrm{et} \mathrm{al.,} \mathrm{2005;} \mathrm{and} \mathrm{Krauss} \mathrm{et} \mathrm{al.,}$ 2006) found that salinity decreased tomato yield and this what has been observed in this study but potassium application either as mono potassium phosphate or potassium humate increased yield under saline condition (Table 6). This is also supported by the finding of Eata (2001) and Economakis and Daskalaki, (2003) who reported an increment in total yield by increasing K application under salinity. Total yield increment may be brought about by increment in average fruit weight and/or increment in fruit number per plant. Average fruit weight improved by K under salinity (Soubeih, 1998; Eata, 
2001) and this what has been observed in this study also (Table 6). As potassium plays a role in assimilates translocation, the application of $\mathrm{K}$ can be expected to improve TSS in the fruits. This is supported by the findings of (Soubeih, 1998; Eata, 2001) who found that TSS of fruit improved by K under salinity. Moreover, salinity reduces the amount of water going to the fruits which means a more concentrated solids in the fruits. This was observed earlier as TSS in fruits increased as salinity increased (Stamatakis et al., 2003; and Olympios et al., 2003).

Effect of hardening treatments:

Salinity hardening treatments as shown in Table (6) for the two seasons of 2005 and 2006 increased plant tolerance to salinity as expressed in the increment in the recorded reproductive growth parameters. The differences among the means of the treatments were significant with the superiority of the medium level hardening of $3000 \mathrm{ppm}$ followed by the high level of $4500 \mathrm{ppm}$ and the least effect but still significantly higher the low level of $1500 \mathrm{ppm}$ compared to control. Ahmed, 2003 reported improvement in mung bean which received salinity hardening.

Table (6): Effect of fertilization and salinity hardening treatments on yield and yield components of V.T. 737 tomato hybrid in the first and second seasons (2005 and 2006)

\begin{tabular}{|c|c|c|c|c|c|c|c|c|c|c|c|}
\hline \multicolumn{2}{|c|}{ Treatments } & \multirow{2}{*}{\multicolumn{2}{|c|}{$\begin{array}{l}\text { No. of } \\
\text { fruits } \\
\text { /plant }\end{array}$}} & \multirow{2}{*}{\multicolumn{2}{|c|}{$\begin{array}{l}\text { Total yield } \\
\text { / plant (gm) }\end{array}$}} & \multirow{2}{*}{\multicolumn{2}{|c|}{$\begin{array}{c}\text { Average } \\
\text { fruit weight } \\
\text { (gm) }\end{array}$}} & \multirow{2}{*}{\multicolumn{2}{|c|}{$\begin{array}{c}\text { Total } \\
\text { yield / fed. } \\
\text { (ton) }\end{array}$}} & \multirow{2}{*}{\multicolumn{2}{|c|}{$\begin{array}{c}\text { TSS } \% \text { for } \\
\text { fruit }\end{array}$}} \\
\hline $\begin{array}{c}\text { Fertilization } \\
\text { (A) }\end{array}$ & $\begin{array}{c}\text { Salinity } \\
\text { hardening }(B)^{*}\end{array}$ & & & & & & & & & & \\
\hline \multicolumn{2}{|l|}{ Seasons } & $1^{\text {st }}$ & $2^{\text {nd }}$ & 1st & $2^{\text {nd }}$ & 1st & $2^{\text {nd }}$ & 1 $^{\mathrm{st}}$ & $2 \frac{\text { nd }}{}$ & 1t & $2^{\text {nd }}$ \\
\hline \multirow{4}{*}{ Control } & Control & 18.33 & 19.33 & 672.67 & 685.33 & 73.67 & 74.67 & 5.53 & 5.70 & 77 & 90 \\
\hline & Low (15 & & 1.00 & & & & 95.00 & 7.63 & 60 & & 24 \\
\hline & Medic & & 0.67 & & & & & 9.23 & 43 & & \\
\hline & High & 26.00 & 8.67 & & & & & & 83 & & 45 \\
\hline \multicolumn{2}{|l|}{ Mean } & 23. & 27.42 & & & & & 7.76 & 89 & & 32 \\
\hline \multirow{4}{*}{$\begin{array}{l}\text { Potassium } \\
\text { Humate }\end{array}$} & Contr & 23.33 & 23.67 & & & & 91.00 & 6.10 & 6.23 & 7.92 & 7.94 \\
\hline & Low (15) & 32.00 & 33.33 & & & 10 & .33 & 8.20 & 8.63 & 18 & 8.72 \\
\hline & Medic & 37.00 & 39.67 & & & & 3.00 & 10.27 & 10.60 & 9. & 9.22 \\
\hline & High & 36.00 & 38.00 & & & & .33 & 9.67 & 10.10 & 8.95 & 9.03 \\
\hline \multicolumn{2}{|l|}{ Mean } & & 33.67 & & & & 67 & 8.56 & 89 & 8.66 & 73 \\
\hline \multirow{4}{*}{$\begin{array}{l}\text { Mono } \\
\text { Potassium } \\
\text { Phosphate }\end{array}$} & Con & 25.67 & 26.33 & & & & & 7.50 & 7.40 & 8. & 7 \\
\hline & Low & & & & & & & 9.80 & 43 & & \\
\hline & Medi & 33 & 0 & & & & & 14.83 & 15.33 & 9. & \\
\hline & High & 49.33 & 53.00 & & & & 67 & 13.30 & 14.27 & 9.39 & .98 \\
\hline \multicolumn{2}{|l|}{ Mean } & 42.83 & 45.08 & & & 127.75 & 135.25 & 11.36 & 11.86 & 8.99 & 9.11 \\
\hline \multirow{4}{*}{ Amino Acid } & Control & 22.00 & 22.67 & & & & 89.67 & 5.90 & 6.00 & 7.89 & 7.90 \\
\hline & Low (15 & 30.33 & 32.33 & 33 & 12 & 106 & 109.67 & 7.97 & 8.27 & 8.55 & 8.65 \\
\hline & Mediu & 33.33 & 38.33 & & & & 122.67 & 9.67 & 10.03 & 8.98 & 9.07 \\
\hline & High & 32.67 & 36.67 & 14 & & 11 & 118.67 & 9.77 & 9.93 & 8.87 & 9.00 \\
\hline \multicolumn{2}{|l|}{ Mean } & 29.58 & 32.50 & & & & & 8.33 & 8.56 & 8.57 & 66 \\
\hline \multirow{4}{*}{$\begin{array}{l}\text { General mean } \\
\text { for }(\mathrm{A}) \\
\text { Treatments }\end{array}$} & & 22.33 & 23.00 & & & & 92 & 6.26 & 6.33 & 7.94 & 95 \\
\hline & Low (1 & 31.08 & 34.42 & 119 & & 107.42 & 113.25 & 8.40 & 8.73 & 8.56 & 8.64 \\
\hline & Mediu & 39.08 & 42.17 & .58 & & 129.42 & 133.58 & 11.00 & 11.35 & 9.07 & 9.21 \\
\hline & High & 36.00 & 39.08 & 15 & .83 & 119.58 & 122.92 & 10.34 & 10.78 & 8.89 & 9.01 \\
\hline \multirow{3}{*}{$\begin{array}{l}\text { L.S.D at } 0.05 \\
\text { for }\end{array}$} & & 0.84 & 2.93 & 86.58 & 97.11 & 5.90 & 5.30 & 0.32 & 0.34 & 0.04 & 0.05 \\
\hline & & 1.27 & 2.17 & 79.20 & 75.13 & 3.52 & 3.35 & 0.19 & 0.24 & 0.06 & 0.05 \\
\hline & $A \times B$ & 2.54 & 4.34 & \begin{tabular}{|l|}
158.39 \\
\end{tabular} & \begin{tabular}{|l|}
150.26 \\
\end{tabular} & 7.04 & 6.69 & 0.37 & 0.49 & 0.12 & 0.11 \\
\hline
\end{tabular}

${ }^{*}$ ppm for salinity

Effect of Interaction: 
Similar to the trends observed in the vegetative growth, the interaction effect of the combined fertilization and hardening treatments showed a cumulative positive effect compared to the control treatment as shown in Tables (6) for the two seasons 2005 and 2006 respectively. The combination of the treatments of mono potassium phosphate and the hardening with the medium level $3000 \mathrm{ppm}$ had the best effect on improving the productivity of tomato plants grown under saline condition. Fruit characteristics also showed a positive and the highest response to the same treatment. All other combinations were also significantly higher compared to control however not as high as the combination of mono potassium phosphate and the hardening level of $3000 \mathrm{ppm}$.

In addition, the application of potassium in other forms such as potassium humate, improved plant growth under saline conditions due to the presence of humic. Humic was reported to increase plant vegetative growth (Turkmen et al., 2004; Dursun et al., 2002; and Arancon et al., 2003) and total plant dry mater production (Arancon et al., 2003; Bohme, 1999). Amino acids improved also plant growth and production under saline conditions. Amino acids were found to increase number of flowers, fruit setting and fruit yield (Neeraja et al., 2005).

All above mentioned explanation are expected to give cumulative effects on plant growth and production as both techniques (fertilization and hardening) are acting in two complementary pathways and these what have been observed in the interaction of the treatments.

\section{Conclusion}

It can be concluded that using hardening techniques at nursery as well as at field condation stage can improve plant tolerance to salinity after transplanting to the open field in salt affected soils. However, using other fertilizers such as mono potassium phosphate can improve this tolerance to a further degree.

\section{REFERENCES}

Abdel-Mawgoud, A.M.R. (2002). Growth and production of greenhouse sweet pepper in relation to root zone conditions. Ph.D. thesis, Humboldt University in Berlin, Germany. 115 pp.

Achilea, O. (2002). Alleviation of salinity induced stress in cash crops by Multi-K (Potassium Nitrate), five cases typifying the underlying pattern. Acta Horticulturae. 573: 43-48.

Agong, S.G.; Y. Yoshida; S. Yazawa and; M. Masuda (2004). Tomato response to salt stress. Acta Horticulturae, 637: 93-97.

Ahmed, Y.M.A. (2003). Adaptation studies on increasing salt tolerance of mung bean plants. M.Sc.Thesis, Fac.Agric Zagazing Univ. (Benha Branch).

Ahmed, Y.M.A. (1998). Response of tomato plants to the salinity of irrigation water. Ph.D. Thesis, Fac. Agric. Zagazig Univ. Benha Branch,. 
Al-Karaki, G.N. (2000). Growth, sodium, and potassium uptake and translocation in salt stressed tomato. Journal of Plant Nutrition, 23 (3): 369-379.

Amico, M.L.; R. Izzo; F. Tognoni; A. Pardossi and F.Navari (2003). Application of diluted Seawater to soilless culture of tomato (Lycopersicon esculentum Mill.): Effect on plant growth, yield, and fruit quality and antioxidant capacity. Journal of food Agriculture and Environment, 1 (2): 112-116.

A.O.A.C. (1990). Official methods of analysis. Association of official analytical chemists. $15^{\text {th }}$ ed. Washington D.C., USA.

Arancon, N. Q.; S. Lee; C.A. Edwards; R. Atiyeh (2003). Effects of humic acids derived from cattle, food and paper-waste vermicomposts on growth of greenhouse plants. Pedobiologia. 47(5/6): 741-744

Bohme, M. (1999). Effects of lactate, humate and Bacillus subtilis on the growth of tomato plants in hydroponic systems. Acta-Horticulturae. ( 481): 231-239

Chapman, H.D. and P.F. Pratt (1961). Methods of analysis for soils, plant and water. Univ. of Calif. Division of agriculture science, August $2^{\text {nd }}$ printing.

Chartzoulakis, K.S. and G. Klapaki (1998). Effects of $\mathrm{NaCl}$ salinity on growth and yield of two pepper cultivars. Acta Hort. 511, p. 143-149

Dursun, A.; I. Guvenc; M. Turan (2002). Effects of different levels of humic acid on seedling growth and macro and micronutrient contents of tomato and eggplant. Acta-Agrobotanica. 55(2): 81-88

Eata, A.E.K. (2001). Response of some tomato cultivars to natural soil salinity and use of some treatments to reduce salt injury. Ph.D. Thesis, Faculty of Agric. Mansoura Univ.

Economakis, C. and A. Daskalaki (2003). Effect of potassium nutrition on yield and quality of tomato plants grown with nutrient film technique under sodium chloride saline conditions. Acta Horticulturae, 609 : 337339.

Ehret, D.L. and L.C. Ho (1986). The effect of salinity on dry matter partitioning and fruit growth in tomatoes in nutrient film culture. Journal Horticultural Science, 61: 361-367.

Gehad, A. (2003). Deteriorated Soils in Egypt: Management and Rehabilitation. EXECUTIVE AUTHORITY FOR LAND IMPROVEMENT PROJECTS (EALIP), Ministry of Agriculture, Egypt.

Gosev, N.A. (1960). Some methods in studying plant water relations, Leningrade A cad of Sciena, USSR.

Hajer, A.S.; A.A. Malibari; H.S. Al-Zahrani and O.A. Almaghrabi (2006). Responses of three tomato cultivars to seawater salinity 1 - Effect of salinity on the seedling growth. African J. of Biotechnology, 5 (10): 855861. (CAB Abstr. 2004-2006).

Hassan, E.H.A. (1999). Physiological studies on the adaptation of some tomato varieties under saline condition. M.Sc. Thesis, Fac. Agric. Ain Shams Univ.

Hayward, H.E. and E.M. Long (1943). Some effects of sodium salts on the growth of tomato. Plant physiology, 18, 556-569. 
Ho, L.C. and P. Adams (1989). Effects of Diurnal changes in the salinity of the nutrient solution on the accumulation of calcium by tomato fruit. Ann. Bot., 64, 373-382.

Jackson, M.L. (1958). Soil chemical analysis. Constable and Co., Itd., London, 38, 325.

Krauss, S.; W.H. Schnitzler; J. Grassmann and M. Woitke (2006). The influence of different electrical conductivity values in a simplified recirculating soilless system on inner and outer fruit quality characteristics of tomato. J. of Agric. and Food Chemistry, 54 (2): 441 448.

$\mathrm{Li}, \mathrm{Y}$. and C. Stanghellini (2001). Analysis of the effect of EC and potential transpiration on vegetative growth of tomato. Scientia Horticulturae, 89 (1): 9-21.

$\mathrm{Li}, \mathrm{Y}$. (2000). Analysis of greenhouse tomato production in relation to salinity and shoot environment. Ph.D. thesis, Wageningen Agricultural university. 95pp.

Livett, J. (1980). Responses of plants to environmental stresses. 2nd ed. Academic Press New York.

Maggio,A.; S. Pascale; G. Angelino; C. Ruggiero and G. Barbieri (2004). Physiological response of tomato to saline irrigation in long-term salinized soils. European Journal of Agronomy, 21 (2): 149-159. (CAB Abstr. 2004-2006).

Mulholland, B.J.; M. Fussell; R.N. Edmondson; J. Basham; J.M. Mckee and N. Parsons (2002). The effect of split-root salinity stress on tomato leaf expansion, fruit yield and quality. Journal of Horticultural Science and Biotechnology, 77 (5): 509-519. (CAB Abstr. 1998-2003).

Neeraja, G.; I. P. Reddy; B. Gautham (2005). Effect of growth promoters on growth and yield of tomato $\mathrm{Cv}$. Marutham .Journal-of-ResearchANGRAU.; 33(3): 68-70

Nofual, E. H. A.; M. K. Sadik; M.F. Attia (2000). Studies on tolerance of some plants to salinity. Annals-of-Agricultural-Science,-Moshtohor.; 38(2): 1329-1346

Olympios, C. M.; I. C. Karapanos; K. Lionoudakis; I. Apidianakis (2003). The growth, yield and quality of greenhouse tomatoes in relation to salinity applied at different stages of plant growth. Acta-Horticulturae. (609): 313-320

Piper, C.S. (1950). Soil and plant analysis. Inter Science Publishers, New york, 213-217.

Pitacco, A.; O. Lain and C. Giulivo (1990). Gas exchange and architecture of sweet pepper as affected by water stress. First congress of the European Society of Agronomy, Colmar, France.

Ragab, R.; N. Malash; G.A. Gawead; A. Arslan and A. Ghaibeh (2005). A holistic generic integrated approach for irrigation, crop and field management 2-The SALTMED model validation Using field data of five 
growing seasons from Egypt and Syria-Agricultural Water Management, 78(1-2): 89-107. (CAB Abstr. 2004-2006).

Sanchez Conde, M.P. and P. Azuara (1979). Effect of balanced solutions with different osmotic pressure on tomato plant. J. plant Nutrition, 1, 297307.

Shibli, R.A.; M. Kushad; G.G. Yousef; M.A. Lila (2007). Physiological and biochemical responses of tomato microshoots to induced salinity stress with associated ethylene accumulation .Plant-Growth-Regulation. 51(2): 159-169

Snedecore, G.W. and Cochran (1991). Statistical methods. $8^{\text {th }}$ ed., lowa State Univ. press, lowa, USA.

Sonneveld, C. (1979). Effects of salinity on the growth and mineral composition of sweet pepper and eggplant grown under glass. Acta Horticulturae, 89: 71-78.

Sonneveld, C. (2000). Effect of salinity on substrate grown vegetables and ornamentals in greenhouse horticulture. Ph.D. dissertation, Wagenignen Agric. Uinv., $151 \mathrm{pp}$.

Soubeih, K.A.A. (1998): Productivity improvement of tomato crop under environmental saline conditions. M. Sc. Thesis, Fac. Agric. Ain Shams Univ.

Stamatakis, A.; N. Papadantonakis; N. Lydakis Simantiris; P. Kefalas; D. Savvas (2003). Effects of silicon and salinity on fruit yield and quality of tomato grown hydroponically. Acta-Horticulturae. (609): 141-147

Taha, E.M.E. (1978): Physiological studies on the hardening process in vegetable crops. Ph. D. Thesis, Fac. Agric., Ain Shams univ. Cairo, Egypt.

Tantawy, A. (2007). Effect of some mineral and organic compounds on salinity tolerance in tomato. Ph.D. thesis. Fac. Agric. Al-Azhar Univ.

Turkmen, O.; A. Dursun; M. Turan; C. Erdinc (2004). Calcium and humic acid affect seed germination, growth, and nutrient content of tomato (Lycopersicon esculentum L.) seedlings under saline soil conditions. Acta-Agriculturae-Scandinavica-Section-B,-Soil-and-Plant-Science. 2004; 54(3): 168-174

Valenzuela, O. R.; C.S. Gallardo (2001). Production of tomato seedling in growing medium formulated with soil .Horticultura-Argentina.; 20(48): $5-10$

Yustseven, E.; G.D. Kesmez and A. Unlukara (2003). The effect of potassium on salinity tolerance, fruit quality and water consumption for tomato (Lycopersicon esculentum) under saline conditions. Sustainable Strategies for irrigation in salt prone Mediterranean Region. a: system approach proceeding of an International Woshop, Cairo, Egypt, 8-10 December,: 192-203.

Zabri, A.W.; S.W. Burrage; K.S. Chartzoulakis (1997). The effects of vapour pressure deficit (VPD) and enrichment with $\mathrm{CO} 2$ on water relations, photosynthesis, stomatal conductance and plant growth of sweet 
pepper (Capsicum annuum L.) grown by NFT. Acta Horticulturae. No. 449, 561-567.

تحسين نمـو وإنتاجية الطمـاطم تحت ظروف الملوحة بإستخدام التسميا والتقسية

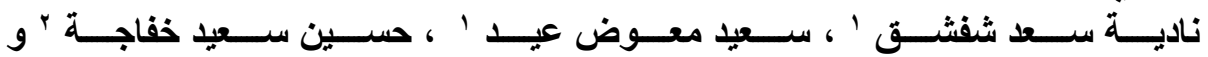

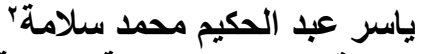

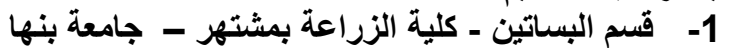

2- مركز بحوث الصحراء ـ قسم الأصول الوراثية ــ وحدة أقلمة نبات

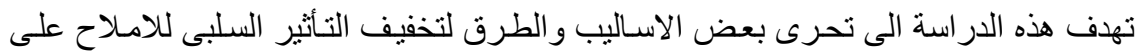

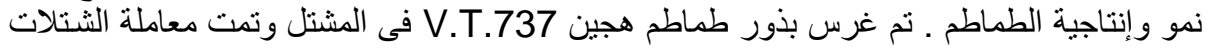

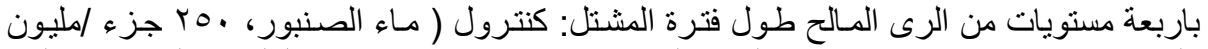

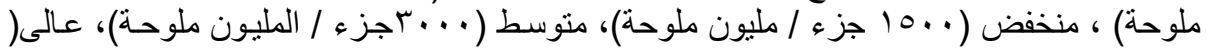

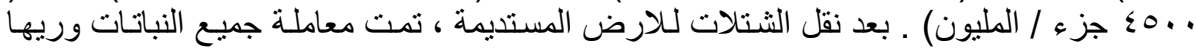

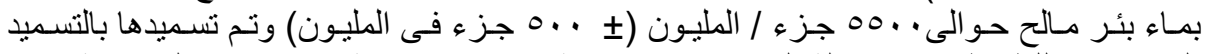

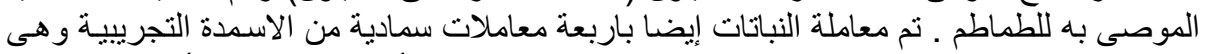

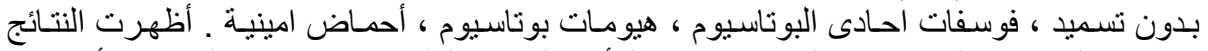

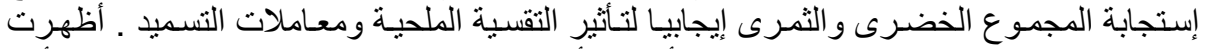

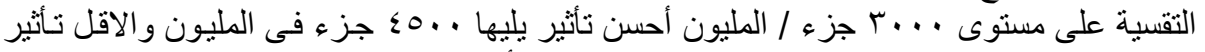

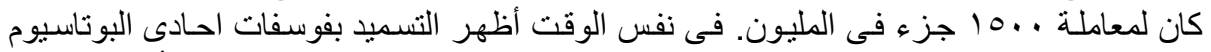

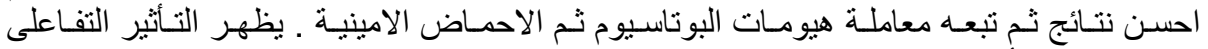
للمعاملات انه تأثير تر اكمى على إستجابة النبات . 